\title{
Field Sprays of Bacillus subtilis and Fungicides for Control of Preharvest Fruit Diseases of Avocado in South Africa
}

\author{
L. Korsten, E. E. De Villiers, F. C. Wehner, and J. M. Kotzé, Department of Microbiology and Plant Pathology, \\ University of Pretoria, Pretoria 0002, Republic of South Africa
}

\begin{abstract}
Korsten, L., De Villiers, E. E., Wehner, F. C., and Kotzé, J. M. 1997. Field sprays of Bacillus subtilis and fungicides for control of preharvest fruit diseases of avocado in South Africa. Plant Dis. 81:455-459.

In 3 consecutive years, preharvest applications of Bacillus subtilis field sprays integrated with copper oxychloride or benomyl consistently reduced severity of avocado black spot (BS), caused by Pseudocercospora purpurea at Omega, Republic of South Africa. Control was equal to that obtained with copper oxychloride or benomyl-copper oxychloride in the first and third years of spraying at Omega. In the second year, only the integrated treatment controlled BS, while copper oxychloride proved ineffective. The antagonist was applied on its own or integrated with copper oxychloride sprays at two other geographically distinct locations, Westfalia Estate and Waterval. The integrated and biological treatments at these localities were less effective than copper oxychloride sprays in controlling BS disease. Integrated control was more effective than B. subtilis sprays at Westfalia. On continuation of the biological spray program at Waterval for an additional three seasons, control was as effective as copper oxychloride in the last 2 years of spraying. Sooty blotch (SB), caused by an Akaropeltopsis sp., was reduced by the integrated treatment at Omega during the second season and at Westfalia during the first season. Although the two fungicide treatments reduced SB at Omega in the first season, copper oxychloride increased it above that of the control in the third season. Only the copper oxychloride treatment reduced SB at Waterval in the third season, while the B. subtilis treatment increased disease above that of the control in the fourth season.
\end{abstract}

Additional keywords: biocontrol, Cercospora spot

Black spot (BS) and sooty blotch (SB), caused by Pseudocercospora purpurea (Cooke) Deighton (8) and an Akaropeltopsis sp. (36), respectively, are the two most important preharvest fruit diseases of avocado (Persea americana Mill.) in South Africa (27). Losses from BS of up to $69 \%$ have been recorded in untreated orchards on the susceptible cultivar Fuerte (7), while SB results in lower market value of fruit due to unsightly discoloration of the skin $(35,36)$. Traditionally, control of BS was based on preharvest benomyl, copper oxychloride, or cupric hydroxide sprays $(6,30,31,41)$. In South Africa, chlorine is occasionally used postharvest to remove the black epiphytic growth of Akaropeltopsis (2). Several disadvantages associated with the repeated use of fungicides on avocados have been noted. These include costs of removing copper spray residues on fruit in the packhouse (10) and buildup of pathogen resistance to benomyl (8). Possible adverse effects of agrochemicals on

Corresponding author: L. Korsten

E-mail: 1korsten@scientia.up.ac.za

Accepted for publication 27 January 1997.

Publication no. D-1997-0312-06R

(C) 1997 The American Phytopathological Society human health and the environment necessitate alternative disease control measures such as biological and integrated control.

Biological control can be effective when antagonists are applied as preharvest treatments to control leaf and fruit diseases such as Cercospora leaf spot on groundnuts caused by Cercospora arachidicola (19), powdery mildew and anthracnose of mango caused by Oidium mangiferae and Colletotrichum gloeosporioides (25), rust on beans caused by Uromyces phaseoli (1), and charcoal rot on potato caused by Macrophomina phaseolina and Botryodiplodia solanituberosi (38). In these examples, Bacillus spp. were used as biocontrol agents (38). Preharvest antagonist sprays have also been effective in controlling postharvest fruit diseases. Korsten (20) and Korsten et al. (22) reported effective control of postharvest decay from anthracnose, stem-end rot (SE), and Dothiorella-Colletotrichum fruit rot complex (DCC) when using preharvest B. subtilis field sprays. Postharvest application of $B$. subtilis was similarly effective for control of these postharvest problems $(20,21)$.

Evaluation of $B$. subtilis for control of the preharvest diseases BS and SB on avocado was therefore an obvious sequel to the successful evaluation of the antagonist as a biocontrol agent of postharvest avocado fruit diseases $(22,25)$. This paper reports on field experiments in which $B$. subtilis, singly or integrated with copper oxychloride or benomyl-copper oxychloride, was compared with commercial chemical control field spray programs for control of BS and SB.

\section{MATERIALS AND METHODS}

Experiments were initiated in the 1990 to 1991 growing season at three geographically distinct sites: Omega, situated near Burgershall (Mpumalanga) (3 years); Westfalia Estate (block 34B) (1 year); and Waterval (block 4) (Northern Province) (4 years). At each site, 15- to 20-year-old Fuerte cultivar avocado trees of the same size, canopy density, and fruit set were selected and marked in a randomized block design. Treatments included commercial benomyl or copper oxychloride sprays, alone or integrated with $B$. subtilis spraying, and B. subtilis sprays alone (Table 1). Five double-tree replicates were used per treatment throughout the duration of the experiment. Unsprayed trees were included as controls in the first year, but the other 2 years at Omega they received one spray of copper oxychloride at the farmer's insistence to prevent inoculum buildup. Prior to initiation of these experiments, trees from all three sites were commercially sprayed with copper oxychloride. Commercial spraying was done during fruit development at the onset of the rainy season (usually the end of October), followed by a November and a January application. At Omega and Waterval, a history of heavy pressure of BS occurred. B. subtilis (B246) isolated from the avocado phylloplane, and which effectively inhibited in vitro and in vivo growth of avocado postharvest pathogens $C$. gloeosporioides, Dothiorella aromatica, Thyronectria pseudotrichia, Phomopsis perseae, Pestalotiopsis versicolor, and Fusarium solani (21), was selected for field sprays. This antagonist effectively controlled anthracnose, SE, and DCC when sprayed in avocado orchards (20) or when used in postharvest wax (21) or dip (24) applications.

B. subtilis (B246) was mass produced for field application as described in a previous study (21). The antagonist formulation was mixed into 500 liters of water in a spray tank to obtain a final concentration of $10^{7}$ cells $\mathrm{ml}^{-1}$. Copper oxychloride $85 \%$ WP (Demildex, Delta Chem, Meyerton, RSA) and benomyl 50\% WP (Benlate, Agrihold, Pretoria, RSA) were prepared in 
separate spray tanks at registered rates $(2.5$ $\mathrm{g}$ a.i. liter ${ }^{-1}$ and $0.4 \mathrm{~g}$ a.i. liter ${ }^{-1}$, respectively). Nu-Film 17 (Hygrotech Seed, Pretoria, RSA) was added at the registered rate of $0.02 \%(\mathrm{vol} / \mathrm{vol})$ to all spray treatments. Each tree was sprayed using highvolume ground sprayers (100 liter) till runoff to obtain full coverage of leaves, fruit, stems, and branches. Application dates of the various treatment programs are shown in Table 1. The fungicide spray dates corresponded with commercial spray dates for each area. Discrepancies in the spray schedules between the different locations were mainly due to differences in rainfall patterns. The integrated management treatment using copper oxychloride and $B$. subtilis also was evaluated at Westfalia and Waterval for 1 year. At the latter two farms, an antagonist-only treatment was also included in the first season (1990 to 1991). Due to a severe drought and subdiscontinued at Westfalia. Thereafter, experiments using the antagonist alone were sequent poor fruit set, experiments were

continued only at Waterval for 3 more consecutive years. During this period, the integrated treatment was discontinued due to the loss of a tree.

During commercial harvest (April), at least 30 fruit were picked randomly from each tree and evaluated on a 0 to 3 scale for BS and a 0 to 4 scale for SB (30) (Fig. 1). Data were analyzed using the Statistical Analysis System (SAS/STAT Mainframe Version 6 ed. 1987. SAS Institute, Cary, NC). A Kruskal-Wallis transformation of data and analysis of variance was performed, and significant differences were determined using Duncan's multiple range test at $P \leq 0.05$.

\section{RESULTS}

In the first season (1990 to 1991), BS was significantly reduced at all three sites by all spray treatments (Table 2). At Omega, the spray regimes were equally effective; whereas at Westfalia and Waterval, the fungicide treatment was significantly better than the $B$. subtilis or inte-

Table 1. Treatment programs and preharvest spray dates of fungicides, Bacillus subtilis (B246) alone and $B$. subtilis integrated with fungicide sprays for control of preharvest avocado fruit diseases

\begin{tabular}{|c|c|c|c|c|c|c|}
\hline \multirow{2}{*}{$\begin{array}{l}\text { Location } \\
\text { Treatment }\end{array}$} & \multirow[b]{2}{*}{ Concentration } & \multicolumn{5}{|c|}{ Month of application } \\
\hline & & Oct. & Nov. & Dec. & Jan. & March \\
\hline \multicolumn{7}{|l|}{ Omega 1990 to 1991} \\
\hline Control & Unsprayed & - & - & - & - & - \\
\hline Copper oxychloride & $2.5 \mathrm{~g}$ a.i. liter $^{-1}$ & + & + & - & + & - \\
\hline Benomyl + & 0.4 g a.i. liter $^{-1}$ & + & - & - & - & - \\
\hline Copper oxychloride & $2.5 \mathrm{~g}$ a.i. liter $^{-1}$ & - & - & + & + & - \\
\hline Benomyl + & $0.4 \mathrm{~g}$ a.i. liter $^{-1}$ & + & - & - & - & - \\
\hline B. subtilis & $10^{7}$ cells ml ${ }^{-1}$ & - & - & + & + & + \\
\hline \multicolumn{7}{|l|}{ Omega 1991 to 1992} \\
\hline Control $^{\mathrm{z}}$ & $2.5 \mathrm{~g}$ a.i. liter $^{-1}$ & + & - & - & - & - \\
\hline Copper oxychloride & $2.5 \mathrm{~g}$ a.i. liter $^{-1}$ & + & + & - & + & - \\
\hline Copper oxychloride + & $2.5 \mathrm{~g}$ a.i. liter $^{-1}$ & + & - & - & - & - \\
\hline B. subtilis & $10^{7}$ cells $\mathrm{ml}^{-1}$ & - & + & + & + & + \\
\hline \multicolumn{7}{|l|}{ Omega 1992 to 1993} \\
\hline Control $^{\mathrm{z}}$ & $2.5 \mathrm{~g}$ a.i. liter $^{-1}$ & + & - & - & - & - \\
\hline Copper oxychloride & $2.5 \mathrm{~g}$ a.i. liter $^{-1}$ & + & + & - & + & - \\
\hline Copper oxychloride + & $2.5 \mathrm{~g}^{\circ}$ a.i. liter ${ }^{-1}$ & + & - & - & - & - \\
\hline B. subtilis & $10^{7}$ cells ml ${ }^{-1}$ & - & + & + & + & + \\
\hline \multicolumn{7}{|l|}{ Westfalia 1990 to 1991} \\
\hline Control & Unsprayed & - & - & - & - & - \\
\hline Copper oxychloride & $2.5 \mathrm{~g}$ a.i. liter $^{-1}$ & - & + & - & + & - \\
\hline Copper oxychloride + & $2.5 \mathrm{~g}$ a.i. liter $^{-1}$ & _- & + & - & - & _- \\
\hline B. subtilis & $10^{7}$ cells ml ${ }^{-1}$ & - & - & + & + & + \\
\hline B. subtilis & $10^{7}$ cells ml ${ }^{-1}$ & - & - & + & + & + \\
\hline \multicolumn{7}{|l|}{ Waterval 1990 to 1991} \\
\hline Control & Unsprayed & - & - & - & - & - \\
\hline Copper oxychloride & $2.5 \mathrm{~g}$ a.i. liter $^{-1}$ & + & + & - & + & - \\
\hline Copper oxychloride + & $2.5 \mathrm{~g}$ a.i. liter ${ }^{-1}$ & + & - & - & - & - \\
\hline B. subtilis & $10^{7}$ cells $\mathrm{ml}^{-1}$ & - & - & + & + & - \\
\hline B. subtilis & $10^{7}$ cells ml $^{-1}$ & - & + & + & + & - \\
\hline \multicolumn{7}{|l|}{ Waterval 1992 to 1993} \\
\hline Control & Unsprayed & - & - & - & - & - \\
\hline Copper oxychloride & 2.5 g a.i. liter ${ }^{-1}$ & + & + & + & + & - \\
\hline B. subtilis & $10^{7}$ cells ml ${ }^{-1}$ & + & + & + & + & - \\
\hline \multicolumn{7}{|l|}{ Waterval 1993 to 1994} \\
\hline Control & Unsprayed & - & - & - & - & - \\
\hline Copper oxychloride & $2.5 \mathrm{~g}$ a.i. liter $^{-1}$ & + & + & + & + & - \\
\hline B. subtilis & $10^{7}$ cells ml ${ }^{-1}$ & + & + & + & + & - \\
\hline \multicolumn{7}{|l|}{ Waterval 1994 to 1995} \\
\hline Control & Unsprayed & - & - & - & - & - \\
\hline Copper oxychloride & $2.5 \mathrm{~g}$ a.i. liter $^{-1}$ & + & + & - & + & - \\
\hline B. subtilis & $10^{7}$ cells ml ${ }^{-1}$ & + & + & - & + & - \\
\hline
\end{tabular}

${ }^{\mathrm{z}}$ One spray of copper oxychloride. grated treatment. B. subtilis was less effective than integrated and fungicide programs at Westfalia. At Waterval, $B$. subtilis sprays and the integrated management treatments were statistically equivalent, but both were less effective than the fungicide sprays. No control of SB was recorded for any of the treatments at Waterval, but both fungicide and integrated treatments significantly reduced this disease at Westfalia (Table 2). Only the fungicide sprays significantly reduced SB at Omega.

The following year (1991 to 1992), significant reductions of $\mathrm{BS}$ and $\mathrm{SB}$ were found only for the integrated treatment at Omega (Table 2). In the 1992 to 1993 season at the same location, the fungicide and integrated treatments were effective against BS. However, significantly higher levels of SB were observed where fungicides alone were used (Table 2). Fungicides alone were effective at Waterval in 1992 to 1993 (Table 2). During the following 2 years (1993 to 1994 and 1994 to 1995 ), the efficacy of B. subtilis was equal to that obtained with the fungicide treatment (Table 2), but only the fungicide sprays controlled SB during 1993 to 1994. In the 1994 to 1995 experiment, SB levels were higher in the B. subtilis treatment than in the control. Fungicides again were ineffective for SB control.

\section{DISCUSSION}

For biocontrol agents to be accepted commercially, it is essential to show consistent control over several years at more than one location (4). In our study, the most consistently effective treatment for BS of avocado was achieved with an integrated program of fungicide and $B$. subtilis sprays. A reduced number of chemical sprays coupled with promising levels of control makes an integrated approach to managing BS disease attractive to the avocado industry in South Africa. The single chemical application in the integrated program may act as a safeguard in years when the weather conditions do not favor antagonist activity (9). Similarly, the biological treatment proved effective at the two locations where it was tested in 1990 to 1991 (Waterval and Westfalia) and also during the last 2 of the 3 years where it was sprayed consecutively at Waterval. During the last 2 years of spraying with $B$. subtilis, control was equal to that achieved with fungicides. Tronsmo and Dennis (39) reported on biocontrol with Trichoderma spp. equivalent to commercial fungicides. Integrated control was more effective than $B$. subtilis spraying in one of the two experiments where it was evaluated. Similarly, Trichoderma harzianum sprayed alone or in combination with dichlofluanid was reported to control natural infections of Botrytis cinerea on apple (40) and grapevine (11). 
Although field applications of biocontrol agents to reduce preharvest diseases have not often met with much success $(18,34)$, we showed that $B$. subtilis, alone or integrated with fungicides, effectively reduced natural infections of P. purpurea, and to a limited extent, Akaropeltopsis sp. (integrated program only). The control obtained here is also unique in the sense that no in vitro evaluations were carried out prior to field evaluations since both pathogens are difficult to isolate, and they grow extremely slowly on agar media. The $B$. subtilis isolate used here (previously shown to be effective against avocado postharvest pathogens [20]) was therefore used directly in field sprays and found to be effective.

According to Swinburne (37), commercial acceptance of biocontrol agents depends on their ability to perform as well as or better than commercial fungicides. During the first season of spraying at Westfalia and Waterval, less effective control of BS was found with the biological and integrated treatments than with the fungicide treatment. This is in agreement with Knudsen and Spurr (19), Cullen et al. (5), and Korsten et al. (25). Acceptable control of plant diseases through biological or integrated treatments is not always evident the first season and therefore requires patience on the part of the grower. In follow-up experiments, the integrated (Omega) and biological (Waterval) treatments proved as effective as the fungicide program. It was also shown that the integrated treatment is consistently more effective over time and location compared with commercial fungicides and therefore has the greatest potential for acceptance by growers. Comparative cost of future commercial B. subtilis spray applications will be similar to that of benomyl but higher than that of copper fungicides (L. Korsten, unpublished). The financial aspect would further support an integrated approach.

Fungicide sprays most effectively controlled BS during the first year of evaluation at each of the locations. It is noteworthy to mention that during the second season at Omega, a very high incidence of BS was recorded on leaves of both control and fungicide-treated trees but not on trees receiving the integrated treatment (L. Korsten, unpublished). During the second season, BS symptoms were also abundant on young green leaves, contrary to the usual association of the disease with older, yellowing leaves (6). Variability in the degree of chemical control has been reported $(12,28,37)$. Factors that may be related to less-thandesirable chemical control include declining levels of fungicide at the targeted site, rendering it ineffective (12), varying conditions under which tests were run (16), and high disease pressure $(31,40)$. An unusually high incidence of BS on leaves at Omega during the second season may account for the relatively poor performance of copper sprays.

Timing of application is of crucial importance in biological control programs (3). In preliminary experiments at Omega in 1989 to 1990 (data not shown), application dates were based on epidemiological data for $P$. purpurea obtained from Westfalia (6). Both fungicide and integrated treatments were initiated in November, and fruit harvested early in the season (March) showed that neither treatment was effective in controlling BS. However, when fruit were harvested late in the season (May), only the fungicide treatment provided significant control. Subsequently, Lonsdale and Scott (32) showed that spore release by the pathogen at Omega occurs earlier than at Westfalia. Applications of B. subtilis aimed at establishing the antagonistic bacteria prior to arrival of $P$. purpurea inoculum resulted in sustained control thereafter.

Effective control of SB using a biocontrol agent has not previously been reported. Control of SB of avocado is difficult to achieve (2); and in practice, farmers depend on copper oxychloride sprays or postharvest treatments in the packhouse (2). However, effective control of SB is essential for commercial production (17) since the epiphytic growth of the fungus leaves unacceptable black blotches on fruit. SB was effectively controlled with fungicide sprays at Omega and Westfalia during the first year and at Waterval during the 1993 to 1994 season. In the third season at Omega, fungicide sprays were associated with an increase in disease above that of the control, while a similar tendency was observed at Waterval in the final year of spraying the biological treatment. Such observations are most often ascribed to the changed balance of naturally occurring microorganisms (13-15). In contrast with its effect on BS, B. subtilis sprayed alone appears to be ineffective against SB. Some control of SB was obtained with the integrated treatment. The inability of $B$. subtilis to reduce SB corresponds with the report by Leben (29), who effectively controlled anthracnose but not powdery mildew when unidentified bacteria were sprayed onto cucumber seedlings in the greenhouse.

Apart from preliminary progress reports for the South African avocado industry $(22,26)$, this is the first report of biological control of avocado preharvest fruit diseases over an extended period of time. To our knowledge, this is also the first study in which control of the black epiphytic growth of Akaropeltopsis sp. using natural antagonists has been investigated. The consistent control of BS shown in this investigation together with its potential for control of SB $(20,23,26)$ makes integrated and, to a lesser extent, biological control a feasible alternative to chemical control in the field. In addition, B. subtilis provided effective control of postharvest diseases of avocado $(20,21,23,24)$, and the merits of combining a pre- and postharvest biocontrol program should be investigated.

The use of B. subtilis in a postharvest environment has been controversial, mainly because of its known ability to produce antibiotics under laboratory conditions. However, B. subtilis has been commercialized as a biocontrol agent for field applications, i.e., Bactophyte (33) for use on several vegetables, Epic and Kodak (Gustafson, Inc., Dallas, TX) to control root diseases on cotton and legumes, Sys-

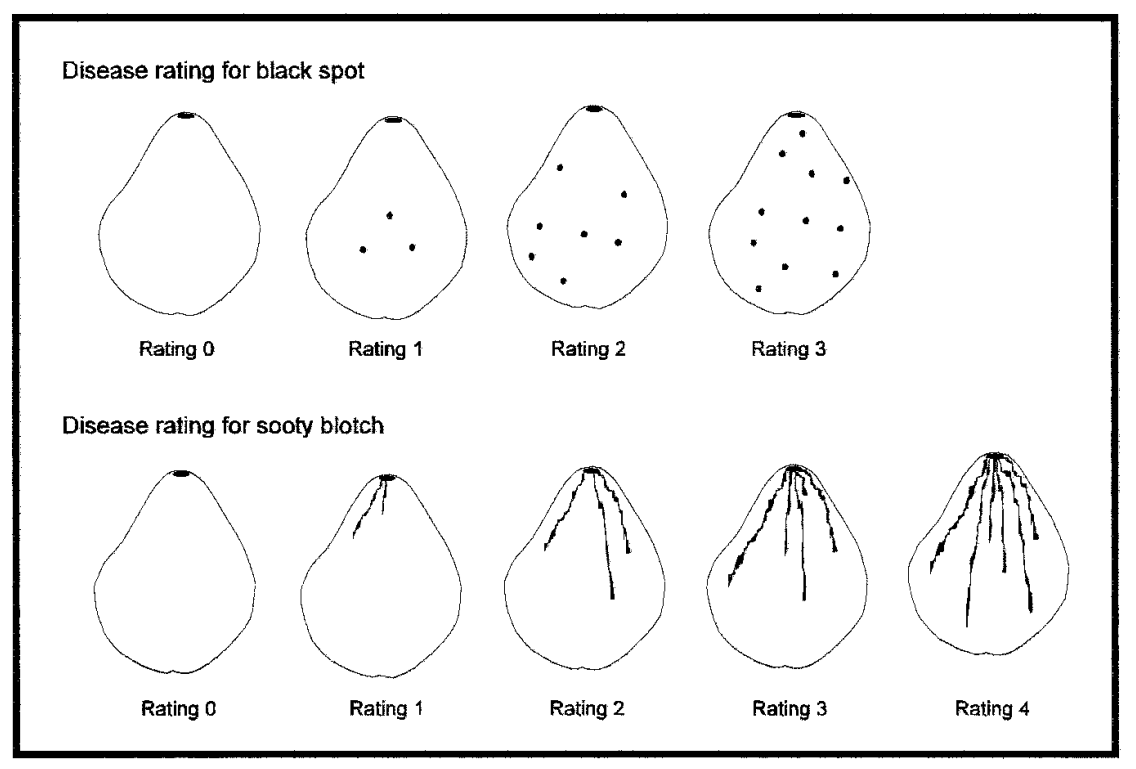

Fig. 1. Avocado fruit disease ratings for black spot, where 0 represents clean fruit, $1=1$ to 5 spots, 2 $=6$ to 10 spots, and $3=>10$ spots; and for sooty blotch, where 0 represents clean fruit, $1=1$ to $10 \%$ of fruit surface area covered, $2=11$ to $25 \%, 3=26$ to $50 \%$, and $4=>50 \%$ of fruit covered. 
tem 3 (Helena Chemical Co., Memphis, $\mathrm{TN}$ ) for control of various seedling pathogens, and Biostart (Advanced Microbial Systems Inc., Shakopee, MN) for control of various fungal pathogens. The potential commercial use of $B$. subtilis in preharvest field applications for control of avocado fruit diseases is therefore a viable option, and future studies should concentrate on elucidating the mode of action of this common natural avocado phylloplane inhabitant (21).

\section{ACKNOWLEDGMENTS}

We thank K. Koekemoer, Omega, Burgershall, and the research staff of Westfalia Estate for making available their avocado orchards for experimental purposes. We also thank James Lonsdale, Constantia Estate, and Riaan Duvenhage, Merensky Technical Services, for their help during field trials and evaluations; Erna Maas for editorial comments; Amanda Lourens, Department of Statistics, University of Pretoria, for statistical analyses; and Daleen Muller for typing. Without the financial support of the South African Avocado Growers' Association, this study would not have been possible.

Table 2. Effect of preharvest field sprays with fungicides, Bacillus subtilis (B246) alone, and $B$. subtilis integrated with fungicides on severity of avocado black spot and sooty blotch

\begin{tabular}{|c|c|c|}
\hline \multirow{2}{*}{$\begin{array}{l}\text { Location } \\
\text { Treatment } \\
\end{array}$} & \multicolumn{2}{|c|}{ Disease severity } \\
\hline & Black spot & Sooty blotch \\
\hline \multicolumn{3}{|l|}{ Omega 1990 to 1991} \\
\hline Control & $1.89 \mathrm{a}^{\mathrm{y}}$ & $1.27 \mathrm{a}$ \\
\hline Copper oxychloride & $0.36 \mathrm{~b}$ & $0.42 \mathrm{~b}$ \\
\hline Benomyl + Copper oxychloride & $0.44 \mathrm{~b}$ & $0.58 \mathrm{~b}$ \\
\hline Benomyl + B. subtilis & $0.72 \mathrm{~b}$ & $1.85 \mathrm{a}$ \\
\hline$F$ value & 104.56 & 63.31 \\
\hline $\mathrm{PR}>F$ & 0.0001 & 0.0001 \\
\hline \multicolumn{3}{|l|}{ Omega 1991 to 1992} \\
\hline Control & $1.34 \mathrm{a}$ & $1.25 \mathrm{a}$ \\
\hline Copper oxychloride & $1.15 \mathrm{a}$ & $1.18 \mathrm{a}$ \\
\hline Copper oxychloride $+B$. subtilis & $0.77 \mathrm{~b}$ & $0.80 \mathrm{~b}$ \\
\hline$F$ value & 23.78 & 17.48 \\
\hline $\mathrm{PR}>F$ & 0.0001 & 0.0001 \\
\hline \multicolumn{3}{|l|}{ Omega 1992 to 1993} \\
\hline Control & $1.73 \mathrm{a}$ & $0.70 \mathrm{~b}$ \\
\hline Copper oxychloride & $1.12 \mathrm{~b}$ & $1.55 \mathrm{a}$ \\
\hline Copper oxychloride $+B$. subtilis & $0.74 \mathrm{~b}$ & $0.89 \mathrm{~b}$ \\
\hline$F$ value & 6.26 & 4.34 \\
\hline $\mathrm{PR}>F$ & 0.0092 & 0.0299 \\
\hline \multicolumn{3}{|l|}{ Westfalia 1990 to 1991} \\
\hline Control & $1.25 \mathrm{a}$ & $0.69 \mathrm{a}$ \\
\hline Copper oxychloride & $0.18 \mathrm{~d}$ & $0.44 \mathrm{~b}$ \\
\hline Copper oxychloride $+B$. subtilis & $0.64 \mathrm{c}$ & $0.51 \mathrm{~b}$ \\
\hline B. subtilis & $0.93 \mathrm{~b}$ & $0.67 \mathrm{a}$ \\
\hline$F$ value & 36.39 & 5.03 \\
\hline $\mathrm{PR}>F$ & 0.0001 & 0.0019 \\
\hline \multicolumn{3}{|l|}{ Waterval 1990 to 1991} \\
\hline Control & $1.77 \mathrm{a}$ & $1.01 \mathrm{a}$ \\
\hline Copper oxychloride & $0.42 \mathrm{c}$ & $1.01 \mathrm{a}$ \\
\hline Copper oxychloride $+B$. subtilis & $1.10 \mathrm{~b}$ & $1.17 \mathrm{a}$ \\
\hline B. subtilis & $1.08 \mathrm{~b}$ & $1.21 \mathrm{a}$ \\
\hline$F$ value & 38.70 & 2.51 \\
\hline $\mathrm{PR}>F$ & 0.0001 & 0.0578 \\
\hline \multicolumn{3}{|l|}{ Waterval 1992 to 1993} \\
\hline Control & $1.67 \mathrm{a}$ & $\ldots^{\mathrm{z}}$ \\
\hline Copper oxychloride & $0.82 \mathrm{~b}$ & $\ldots$ \\
\hline B. subtilis & $1.88 \mathrm{a}$ & $\ldots$ \\
\hline$F$ value & 6.51 & \\
\hline $\mathrm{PR}>F$ & 0.0044 & \\
\hline \multicolumn{3}{|l|}{ Waterval 1993 to 1994} \\
\hline Control & $2.01 \mathrm{a}$ & $1.03 \mathrm{a}$ \\
\hline Copper oxychloride & $1.17 \mathrm{~b}$ & $0.28 \mathrm{~b}$ \\
\hline B. subtilis & $1.48 \mathrm{~b}$ & $1.45 \mathrm{a}$ \\
\hline$F$ value & 9.11 & 16.29 \\
\hline $\mathrm{PR}>F$ & 0.0009 & 0.0001 \\
\hline \multicolumn{3}{|l|}{ Waterval 1994 to 1995} \\
\hline Control & $0.61 \mathrm{a}$ & $1.17 \mathrm{~b}$ \\
\hline Copper oxychloride & $0.27 \mathrm{~b}$ & $1.02 \mathrm{~b}$ \\
\hline B. subtilis & $0.15 \mathrm{~b}$ & $1.76 \mathrm{a}$ \\
\hline$F$ value & 9.59 & 4.74 \\
\hline $\mathrm{PR}>F$ & 0.0007 & 0.0173 \\
\hline
\end{tabular}

${ }^{y}$ Means within columns for each location and each year evaluated followed by the same letter do not differ significantly $(P=0.05)$ according to Duncan's multiple range test. Values represent mean disease severity. Fruit was evaluated on a 0 to 3 scale for black spot and on a 0 to 4 scale for sooty blotch (Fig. 1).

${ }^{\mathrm{z}}$ Not monitored due to low disease incidence.

LITERATURE CITED

1. Baker, C. J., Stavely, J. R., and Mock, N. 1985. Biocontrol of bean rust by Bacillus subtilis under field conditions. Plant Dis. 69:770-772.

2. Bezuidenhout, J. J. 1991. Verwydering van roetvlek vanaf avokadovrugte. S. Afr. Avocado Growers' Assoc. Yearb. 14:60.

3. Bhatt, D. D., and Vaughan, E. K. 1962. Preliminary investigation on biological control of gray mold (Botrytis cinerea) of strawberries. Plant Dis. Rep. 46:342-345.

4. Cook, R. J. 1993. Making greater use of introduced microorganisms for biological control of plant pathogens. Annu. Rev. Phytopathol. 31:53-80.

5. Cullen, D., Berbee, F. M., and Andrews, J. H. 1984. Chaetomium globosum antagonizes the apple scab pathogen, Venturia inaequalis under field conditions. Can. J. Bot. 62:18141818

6. Darvas, J. M. 1982. Etiology and control of some fruit diseases of avocado (Persea americana Mill.) at Westfalia Estate. D.Sc. (Agric.) thesis. University of Pretoria, Pretoria.

7. Darvas, J. M., and Kotzé, J. M. 1987. Avocado fruit diseases and their control in South Africa. S. Afr. Avocado Growers' Assoc. Yearb. 10:117-119.

8. Darvas, J. M., Kotzé, J. M., and Wehner, F. C 1987. Pathogenicity of fungi causing pre- and postharvest diseases of avocado fruit. Phytophylactica 19:489-493.

9. De Cal, A., Sagasta, E. M., and Melgarejo, P. 1990. Biological control of peach twig blight (Monilinia laxa) with Penicillium frequentans. Plant Pathol. 39:612-618.

10. Denner, F. D. N., and Kotzé, J. M. 1986. Evaluasie in vitro van die effektiwiteit van swamdoders teen Colletotrichum gloeosporioides en Dothiorella aromatica. S Afr. Avocado Growers' Assoc. Yearb. 8:48 51.

11. Dubos, B. 1984. Fungal antagonism in aerial agrobiocenoses. Pages 107-135 in: Innovative Approaches to Plant Disease Control. I. Chet, ed. John Wiley \& Sons, New York.

12. Ferreira, J. H. S., Matthee, F. N., and Thomas, A. C. 1991. Biological control of Eutypa lata on grapevine by an antagonistic strain of $\mathrm{Ba}$ cillus subtilis. Phytopathology 81:283-287.

13. Furtado, I. 1969. Effect of copper fungicides on the occurrence of the pathogenic form of Colletotrichum coffeanum. Trans. Br. Mycol. Soc. 53:325-328.

14. Gibbs, J. N. 1972. Effects of fungicides on the populations of Colletotrichum and other fungi in bark of coffee. Ann. Appl. Biol. 70:35-47.

15. Griffiths, E. 1981. Iatrogenic plant diseases. Annu. Rev. Phytopathol. 19:69-82.

16. Hagedorn, C., Gould, W. D., and Bardinelli, T. R. 1993. Field evaluations of bacterial inoculants to control seedling disease pathogens on cotton. Plant Dis. 77:278-282.

17. Hendrix, F. F., Jr. 1991. Removal of sooty blotch and flyspeck from apple fruit with a chlorine dip. Plant Dis. 75:742-743.

18. Knudsen, G. R., and Hudler, G. W. 1987. Use of computer simulated model to evaluate a plant disease biocontrol agent. Ecol. Modelling 35:63-84.

19. Knudsen, G. R., and Spurr, H. W., Jr. 1987. Field persistence and efficacy of five bacterial preparations for control of peanut leaf spot. Plant Dis. 71:442-445.

20. Korsten, L. 1993. Biological control of avocado fruit diseases. Ph.D. thesis. University of Pretoria, Pretoria

21. Korsten, L., De Jager, E. S., De Villiers, E. E., Lourens, A., Kotzé, J. M., and Wehner, F. C. 1995. Evaluation of bacterial epiphytes isolated from avocado leaf and fruit surfaces for 
biocontrol of avocado postharvest diseases. Plant Dis. 79:1149-1156.

22. Korsten, L., De Villiers, E. E., Duvenhage, J. A., and Kotzé, J. M. 1994. Control of avocado preharvest diseases with Bacillus subtilis and fungicide sprays. S. Afr. Avocado Growers' Assoc. Yearb. 17:32-34.

23. Korsten, L., De Villiers, E. E., Wehner, F. C., and Kotzé, J. M. 1994. A review of biological control of postharvest diseases of subtropical fruits. Pages 172-185 in: Postharvest Handling of Tropical Fruits. B. R. Champ, E. Highley, and G. I. Johnson, eds. ACIAR 50, Proc. Int. Conf. Chiang Mai, Thailand.

24. Korsten, L., and Kotzé, J. M. 1993. Postharvest biological control of avocado postharvest diseases. Proc. World Avocado Congr., 2nd. University of California, Riverside, and California Avocado Society 2:473-478.

25. Korsten, L., Lonsdale, J. H., De Villiers, E. E., and De Jager, E. S. 1992. Preharvest biological control of mango diseases. S. Afr. Mango Growers' Assoc. Yearb. 12:72-78.

26. Korsten, L., Lonsdale, J. H., De Villiers, E. E., and Kotzé, J. M. 1992. Effect of Bacillus subtilis and fungicide sprays for control of preharvest diseases of avocado. S. Afr. Avocado Growers' Assoc. Yearb. 15:9-11.

27. Kotzé, J. M., and Darvas, J. M. 1985. Symptoms and causes. S. Afr. Avocado Growers' Assoc. Yearb. 8:29-33.
28. Kotzé, J. M., Du Toit, F. L., and Du Rand, B. J. 1982. Pre-harvest chemical control of anthracnose, sooty blotch and Cercospora spot of avocados. S. Afr. Avocado Growers' Assoc. Yearb. 5:17-18.

29. Leben, C. 1964. Influence of bacteria isolated from healthy cucumber leaves on two leaf diseases of cucumber. Phytopathology 54:405-408.

30. Lonsdale, J. H. 1991. Control of preharvest fruit diseases of avocado Part 1: The efficacy of various Triazole fungicides against Cercospora spot and sooty blotch. S. Afr. Avocado Growers' Assoc. Yearb. 14:61-62.

31. Lonsdale, J. H. 1992. Evaluation of systemic fungicides as preharvest treatments of avocados. S. Afr. Avocado Growers' Assoc. Yearb. 15:35-38.

32. Lonsdale, J. H., and Scott, M. P. 1991. Control of preharvest fruit diseases of avocado Part 2: A preliminary report on the effects of spray timing on the incidence of Cercospora spot of avocados in the Burgershall area. S. Afr. Avocado Growers' Assoc. Yearb. 14:6364.

33. Lumsden, R. D., Lewis, J. A., and Fravel, D. R. 1995. Formulation and delivery of biocontrol agents for use against soilborne plant pathogens. Pages 165-182 in: Biorational Pest Control Agents. F. R. Hall and J. W. Barry, eds. American Chemical Society, Washington,
DC.

34. Peng, G., and Sutton, J. C. 1991. Evaluation of microorganisms for biocontrol of Botrytis cinerea in strawberry. Can. J. Plant Pathol 13:247-257.

35. Pieterse, C. L. 1986. Afkeuringsfaktore by uitvoeravokado's. S. Afr. Avocado Growers' Assoc. Yearb. 10:14.

36. Smith, E. M., Kotzé, J. M., and Wehner, F. C. 1985. Sooty blotch of avocado caused by Akaropeltopsis sp. Phytophylactica 17:101102.

37. Swinburne, T. R. 1978. The potential value of bacterial antagonists for the control of apple canker. Ann. Appl. Biol. 89:94-95.

38. Thirumalachar, M. J., and O'Brien, M. 1977. Suppression of charcoal rot in potato with a bacterial antagonist. Plant Dis. Rep. 61:543546.

39. Tronsmo, A., and Dennis, C. 1977. The use of Trichoderma species to control strawberry fruit rots. Neth. J. Plant Pathol. 83:449-455.

40. Tronsmo, A., and Ystaas, J. 1980. Biological control of Botrytis cinerea on apple. Plant Dis. 64:1009.

41. Vermeulen, J. B., Krause, M., Nel, A. Hollings, N., and Greyling, J. 1992. A guide to the use of pesticides and fungicides in the Republic of South Africa. Directorate of Livestock Improvement and Agricultural Production Resources, Pretoria. 